changes in outlook occurred and dramatic advances were made in the fields of preventive medicine and therapeutics. His early work was performed at a time when the technical armamentarium of bacteriologists was restricted; but he used the simplest procedures with ingenuity and with a consummate artistry which was delightful to see: indeed, he recalled what Max Gottlieb in "Martin Arrowsmith" regarded as the ideal research worker-one who fabricated his apparatus from a packet of tooth-picks.

Gordon's early investigations included the study of water-borne enteric fever, and in this, along with the late Surgeon-Colonel Reece, he carried out some of the earliest work on chlorination of water supplies. His study of the Streptococcus led him to believe that that micro-organism was the causal agent of scarlet fever and, although he failed to prove the validity of his views, his work made possible those later investigations upon which it is now accepted that that malady is due to infection with Streptococci. This work assisted greatly those who in later years defined clearly the mechanism of the pathology of scarlet fever and elaborated means for preventing that illness. As a bacteriologist, perhaps the most fruitful period of his life was during the First World War, when he was called upon to deal with cerebrospinal fever in the Armed Forces. The work which he performed, along with the team he so ably led, did much to elucidate the epidemiology, the bacteriological and the immunological problems of that malady which has proved a scourge to armies throughout history. The account of these investigations, embodied in a report to the Medical Research Council (Special Report Series No. 50; 1920), remains a classic.

In his later years Gordon devoted his attention to the study of virus diseases, notably the 'pock' infertions, and he elaborated a procedure for the diagnosis of smallpox which, prior to the introduction of culture on the chorio-allantoic membrane of the developing chick, was the only accurate and delicate method whereby a diagnosis of modified smallpox or of smallpox minor could be made quickly. The Gordon flocculation test for the diagnosis of smallpox was used successfully to control more than one outbreak of smallpox minor, which presents problems of peculiar difficulty to the public health service. He played an important part in co-ordinating the work of those who contributed to the Rose research on lymphadenoma, and his interest in lymphadenoma was maintained throughout the remaining years of his life.

For many years Gordon was a member of the Advisory Committee on Pathology to the War Office, and for his services to his country he was rewarded by the conferment of the C.M.G. and C.B.E., while his contributions to the advance of knowledge earned for him the fellowship of the Royal Society and, perhaps what gave him most pleasure of all, an honorary LL.D. from the University of Edinburgh. A trait in his character which endeared him to all was that he accepted these honours as an appreciation not only of his own worth but as a recognition of the help he received, and which was given so willingly, by his collaborators.

W. J. Tulloch

\section{Dr. Willoughby Gardner}

Dr. Willoughby Gardner, who died on June 29 in his ninety-fourth year, was of Lancashire stock and the elder son of the late Henry Gardner, of
Birkenhead, and of Caroline Huffam Gardner, née Willoughby. Educated at Rugby, he went into his father's business at Liverpool but retired as a comparatively young man for health reasons, and settled at Deganwy ; there his numerous activities made him for many years a notable figure in the cultural life of Wales. He developed an area of land there as a unique building estate, under regulations which provided that the purchaser of each plot (already planted with trees and flowering shrubs) should build a house of character in keeping with the surroundings.

His early enthusiasm for fishing led him to the study of entomology; as far back as 1901 he published a list of the Hymenoptera Aculeata of Lancashire and Cheshire, and this group was his special interest. His collection of British Aculeate Hymenoptera, including material from North Wales, was presented by him about two years ago to the Zoology Department of the National Museum of Wales. $\mathrm{H}_{\Theta}$ was a Fellow of the Linnæan and the Royal Entomological Societies, and also of the Society of Antiquaries. His presidential address in 1928 to the Lancashire and Cheshire Entomological Society, dealing with the sixteenth-century entomologist Thomas Penny, shows a happy combination of his zoological and antiquarian interests, and was the result of much research.

A keen archæologist, Dr. Gardner was long a leading member of the Cambrian Archæological Association and of its various committees, and president in 1926. In his presidential address, published in Archoeologia Cambrensis of that year, he summed up the results of his work on the significance and history of the great hill-forts of North Wales, many of which he had personally surveyed and planned, besides excavating those of $\mathrm{Y}$ Corddyn and Dinorben in Denbighshire. He was also a prime mover in organizing the excavation of the Roman sites of Segontium at Cærnarvon (by Sir Mortimer Wheeler) and of Kanovium at Cærhun on the River Conway (by Mr. Baillie-Reynolds). He was an original member of the Ancient Monuments Advisory Board for Wales, and of the Wales Advisory Committee of the National Trust and of the Board of Celtic Studies of the University of Wales. In recognition of his work in this sphere the University of Wales conferred on him in 1927 the honorary degree of doctor of science.

His interest in numismatics (he was a Fellow of both the British and the Royal Numismatic Societies) led to the formation, during nearly seventy years of his life, of a fine collection of Anglo-Saxon coins of the Chester Mint, which is now in the Grosvenor Museum at Chester.

One remembers Gardner as a man of wide interests, of great energy in pursuing them, and of "a nature sloping to the southern side".

\section{Colin Matheson}

WE regret to announce the following deaths:

Mr. W. A. Dillon-Weston, chief plant pathologist for the eastern province of the National Agricultural Advisory Service, on August 20, aged fifty-four.

Prof. C. Leonard Huskins, professor of botany in the University of Wisconsin, aged fifty-five.

Prof. L. Prandtl, For.Mem.R.S., of the University of Göttingen, aged seventy-eight.

Mr. T. Raymont, formerly principal of the Goldsmiths' College, University of Iondon, on August 13, aged eighty-eight. 